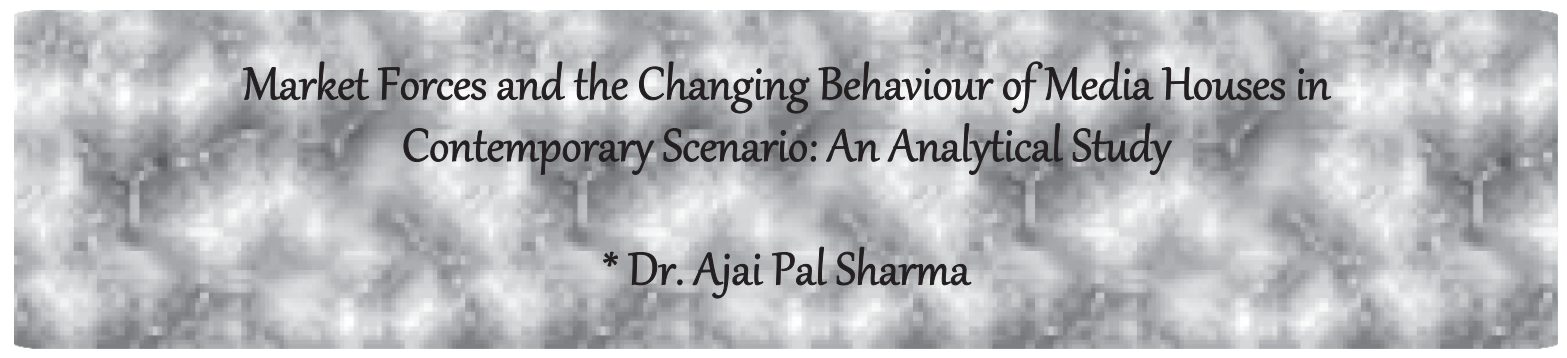

Effulgence

Vol. 12 No. 1

January - June, 2014

Rukmini Devi Institute of Advanced Studies

E-mail : effulgence@rdias.ac.in, Website : www.rdias.ac.in

http://effulgence.rdias.ac.in/user/default.aspX

Abstract

https://dx.doi.org/10.33601/effulgence.rdias/v12/i1/2014/97-103

\begin{abstract}
knowledge from one generation to another and has helped him learn from both success and failure for the progress and growth of mankind. Everyone in this universe has full freedom and power to express his happiness or show discontent with the status quo and demand for a change. The right to freedom of speech has been recognized as a human right under Article 19 of the UDHR (Universal Declaration of Human Rights) and recognized in international human rights law in the International Covenant on Civil and Political Rights (ICCPR). Media is considered as the fourth pillar of democracy but questions are being raised on media today that it is not showing what needs to be shown in the real form. There must be different types of pressures from different sections of the society which compels the media houses to speak their languages to survive in the competitive market. Journalism may claim that it is the voice of the nation but people don't believe as there are enough evidences that it is the mouthpiece of business houses. There are various newspapers or magazines which are owned by the corporate houses and speak their languages. So it can be said that in the contemporary environment media houses are under various pressures which compel them to write or speak which brings them more business. This paper is an attempt to find out various factors and reasons which has impacted the media houses in the contemporary times and changed their priorities.
\end{abstract}

Keywords: Discontent, UDHR, ICCPR, Contemporary, Pillar

\section{INTRODUCTION AND REVIEW OF THE PROBLEM}

$\mathrm{F}_{\mathrm{s}}$ reedom of communicating the ideas and opinions is one of the most precious of the rights of mankind which can be discussed from various perspectives and one of these perspectives can be the real existence of democracy as well as human dignity. It is very much true that the power of expression has allowed man to exchange knowledge from one generation to another and has helped him learn from both success and failure for the progress and growth of mankind. This expression may take different forms, be it written, oral, pictorial, cartoons, or passed through other different signs or means. Everyone in this universe has full freedom and power to express one's happiness or show discontent with the status quo and demand for a change. The right to freedom of speech is recognized as a human right under Article 19 of the UDHR (Universal Declaration of Human Rights) and recognized in International Human Rights Law in the International Covenant on Civil and Political Rights (ICCPR).
This paper was presented in National Conference on 'Freedom of Expression: Ethical Parameters and Market Forces in Media Industry' organized by Maharaja Agrasen College, University of Delhi on 8-9 Feb 2013.
The author is indebted and thankful to Prof. HS Chandalia of Central University of Haryana for providing his valuable insights in writing this paper.

Assistant Professor, Department of Management Studies, School of Law, Governance, Public Policy and Management, Central University of Haryana, Jant-Pali Villages, Mahendergarh 
But what is happening today is the real matter for concern and needs serious discussion. Media is considered as the fourth pillar of democracy but questions are being raised on media today that it is not showing what needs to be shown in the real form. There must be different types of pressures from different sections of the society which compels the media houses to speak their languages. Both print and electronic media have been at the receiving end of gagging acts by various market forces. An American Commission on Freedom of Press stated in its report (1),

"Freedom of Press is essential to political liberty, where men cannot freely convey their thoughts to one another, no freedom is secure. Where freedom of expression exists, the beginning of a free society and means for retention of liberty, are already present. Free expression is, therefore, unique among liberties. It is the 'matrix', the indispensable condition of nearly every other form of freedom."

But today the freedom of press seems to be missing, may be possibly due to various market forces which compel the media houses to bow in front of these market pressures. Media serve not just to disseminate information to the masses but is the maker of the public opinion. Even the impact of media is such that it impacts the public policies and sets an agenda after filtering the information. The selection of media offering has to be at that level so that the reporters and editors can give final shape to the information to be disseminated to the general public. McCombs and Shaw defined it as (2),

"The impact of the mass media-the ability to effect cognitive change among individual, to structure their thinking-has been labeled the agenda-setting function of mass communication. Here may lie the most important effect of mass communication, its ability to mentally order and organize our world for us. In short, the mass media may not be successful in telling us what to think, but they are stunningly successful in telling us what to think about."

The agenda setting can be at three levels; media agendathe process of assigning priorities to the subjects to be discussed by the media, public agenda-the impact of these priorities on the public opinion and policy agenda means how these opinions and reactions are helpful in giving shape to the government policies. But the media operates in a societal set up and competitive environment being surrounded by different types of market forces directly or indirectly and cannot afford to oppose, if it has to survive. The records says that there are 812 licensed television channels which includes 338 news channels including 215 Hindi news channels (out of 338) and the market size of television is nearly 38000 crores which comprises of 25000 crore from pay channels and 13000 crore comes from the advertising. It is well known that lot of money is required to run either any channel or newspaper which generally gives rise to a big question; where from that money will come to run all these channels and the answer can be found that the market can only help the channels to run on 24 hour basis through their advertising costs. So when it comes to the survival issue and beat the competitors in the market than there is no way that one can avoid markets but would like to take advantage of it. In this course of action the channels starts depending on them to meet their increasing expenditures and are bound to move as per their requirements. This can be noticed while watching news channels where the newsreaders generally emphasis going into commercial breaks that clearly shows the demanding position of the advertiser who has paid heavy money to that channel. Let us discuss and deliberate upon various market forces which may be responsible for this type of developments in media houses.

\section{Rationale and Objectives of the Study}

Today it is clearly seen that how the media houses are being hijacked and overpowered by various market forces resulting in meeting the objectives of market forces rather than bringing out the real and emerging issues of the society, to inform and aware the society, which has taken a back seat in both the mediums either electronic or print. The economic and business implications of this new phenomenon in the present context has attracted promoters and advertisers towards media houses in order to grab some share and reaching out to the larger audiences through media. This article aims to find out various market forces which are mainly responsible for this concern and if possible, what can be the alternatives to overcome this problem. 


\section{Research Methodology}

Methodology used for writing this paper is purely exploratory in nature considering views from various experts in this field, Television debates, various newspapers, inputs received from conferences and seminars based on this theme and of course the subjective ideas of the author has also been included. This paper was also presented at a National Conference held by one of the leading colleges of University of Delhi and the inputs received from the experts from that conference are also being considered and incorporated in this paper.

\section{Various Market Forces Impacting Behaviour of Media Houses}

\section{Advancement and Application of Technology}

No doubt that the advancement in the technology has brought revolution in the world of journalism too and has made the presentation better, competitive and has given opportunity to improve the content, quality and appeal of the programs. But this emergence of new communication technology and increasing globalization has brought forth a set of new challenges and opportunities too for the media houses. Especially the emergence and increasing use of internet has posed a challenge for the print media. This has also happened because the reading habits of the consumers are changing and most of the young generation and techno savvy people, who are constraints of time, visit on the internet whether they need to update themselves about the happenings in the country or it may be the matter of any type of purchase. These changing habits and the increasing attraction because of the improved technology have given chance to the media houses to tie up with the advertisers so that they can reach to the readers of the internet information. The results show that whenever we open any website on internet we are bound to see the advertisements whether we like it or not.

\section{Increasing Market Oriented Competition}

The increasing competition of expansion of media industry has given acceleration to the growth of this industry resulting in many mergers and alliances. Due to these alliances the corporate are investing in the media houses so that their interest can be protected the way they desire to do so. This is only because of market oriented competition keeping in view of the shared interest of the shareholders i.e. corporations. But this is not a healthy sign for the media industry and requires serious deliberations on how to keep the dominance of market forces away from the freedom of expressing themselves as they want. As far as the television is concerned the fierce competition for viewership and advertising is making the shots and all channels are being viewed as a profit making ventures. In addition to this the increasing number of media houses is also one of the strong market forces which see the 'packaging of news' as an essential requirement to earn more and more money. Hence increasing competition has decreased the quality of contents and the most prominent place (including front page) in the newspaper is given to the advertisers. It is reported that 75 percent of the newspaper readers are being shared by Times of India and Hindustan Times (16 daily English newspapers), 5 percent by Economic Times and rest 20 percent is shared by all other newspapers. The weight of the TOI is increasing day by day only because they need to create more and more advertising space and that clearly shows the impact of marketing on the media houses.

\section{Globalization and Foreign Direct Investment}

Due to globalization the global media barons have got access to invest and dominate in the India media houses. After the government allowed Foreign Direct Investment in media more Multi National Corporations have started investing in Indian media resulting into making the competition tougher. One of the most disturbing developments in the recent years is that the media is spinning out of control, that it is being blown whichever way the winds of consumerism and globalization take it. Today we are living in the globalized world and as more and more FDI is being allowed all over the country which requires space to advertise them and nothing can be the better source than the electronic or print media and in this way they purchase the media houses and start running them as per their wish and direction. 


\section{Revenue Generation the Sole Objective}

For all the media houses revenue generation has become the sole motive irrespective of the way it is being generated. To achieve this sole objective they don't even hesitate using unhealthy social practices, may be by promoting harmful consumer products. In this race social and serious content is generally being replaced by celebrity gossips, sexually attractive pictures and other colorful stories. Economic and commercial compulsions of free market have pushed newspaper to give more space to entertainment news which gets more attraction of urban class instead of serious content on the social issues resulting into revenue generation as the sole objective and driver of the market. But it is also evident that a major portion especially the rural class is unable to afford all these. The records say that nearly 90 percent of income to media houses is generated through advertising modes and if it is true then there is no doubt that media houses are being impacted highly by the market forces in the contemporary scenario.

\section{Catering to the Needs of Handful Market Forces}

The increasing involvement of corporate in the media houses has pressurized them to speak their languages. Even extra pages in newspaper are being added for special coverage on the subjects; like environment, health, science, gender, law and others, which were largely ignored before, to give space to those who have overpowered media through money power. Most of the magazine's covers are also dominated by wide range of family events to earn more and more money from the advertisers and become habitual of doing that resulting into speaking the languages of the handful corporate forces in the long run. This all is happening to fulfill the desires of the handful people who run the corporate that include those who pretend to be the media houses.

\section{Dramatic Increase in Advertising}

Today we are living in a market economy and are compelled to move with the winds of the market. General Secretary of South Asian Free Media Association, Imtiaz Alam, agreed that corporatization of media is the increasing fashion where both the format and content are being decided by the advertisers/sponsors instead of editors. While Editor-inchief of English newspaper The Hindu, N. Ram concludes that "we can't have walls between the editorial functions and the marketing functions but have to draw a line." He did not explain any features of this so called 'line'. One can think that so-called line between the advertisements and the news is diminishing quickly as advertising is a main source of income for marketoriented media corporations which make them dependable on advertisers and as a result the advertisers are demanding steeper and quicker results from media industry and incursion in media contents and if media houses are unable to do that they are likely to lose the market share and the fear of losing the market share compel them to go the way the advertiser want them to do.

\section{Changing Priorities of the Media Houses}

The priorities of the channels are changing in today's environment in comparison to the earlier times. As per the very reliable media sources (name not disclosed) Shri Rajdeep Sardasai, the well know journalist of the country, once used to shut the doors of the meeting room for the marketing people as the top priority was given to the contents and not to any other matter and as the time changed the same person started closing the meeting in between when the marketing people requires to meet him on the issue of hiring space by the advertisers/marketers. This could be possible only because of the changing priorities of the channels because they need to run the channel and channel can't be run if there is no money and money is being made available by the advertisers by finding a suitable place in the channel, newspaper or any magazine. This is the impact of market forces on the media houses to which shows how the priorities of the media houses have changed on e the period of times.

\section{Conflicting Demands of Sponsors and Audiences}

Media houses are under constant pressure to put their interest ahead of everything, due to which the public interest is subordinated. Everyone know that the sponsor's interests are short term whereas the public interest is of long term consisting of various social issues and developmental issues but the public interests are 
being overlooked when compared with the sponsors interests. Let us take the example of Times of India; one of the leading newspapers in India has become an urban glamorous paper which was considered being a pro establishment serious paper. The line between management and editorial policy has become blurred and its circulation is touching huge numbers. Hence the media industry is increasingly defined as being what the audiences are interested in but if we analyze seriously then in real sense they are running away from their responsibilities. The research shows that owner of Times of India i.e. Bennett \& Coleman invests up to $15 \%$ equity in different entrepreneur companies and in return helps them to promote their brand on special rates and give coverage to these companies. So both the media houses as well as corporate are helping each other to take maximum benefits to their credit and that is only because of their own interest than the interest of the general public.

More to Please the Advertisers than to inform the Audiences

Due to increasing pressure from the advertisers even the auto section is designed in the newspapers to create a market place for advertisers and the practice of selecting news in order to make advertising more effective is becoming so common that it has achieved the status of scientific precision. Media depends on advertising for survival, which in turn obeys the dictates of the tiny community of big business houses and corporate. It is estimated that 80 percent of revenue for media houses generally come from advertising. According to a research by Centre of Media Studies (CMS), only 8 percent of prime time television news covered development issues in 2008 which indicates the relationship between the media houses and other corporate or political giants involved in such corporate. Most of the front pages of the newspapers is found full of advertising in today's competitive environment which is the confirmed proof that how market has impacted the media houses.

\section{Appointment of Editors}

Even the appointment of the Editors is being influenced by market forces and he is forced to bring business otherwise his job may be on risk. Today even Editors are not in a position to enjoy their freedom of expression because of various pressures in the world of media which has become purely profit oriented. In the older times editors were at their freedom to choose the news to be included in their newspapers but today they have to give priority to the advertisements over news because it brings heavy amount of money to the media houses, may it be from the corporate world or any other sources.

Journalism may claim that it is the voice of the nation but people don't believe as there are enough evidences that it is the mouthpiece of business houses. There are various newspapers or magazines which are owned by the corporate houses and speak their languages. So it can be said that in the contemporary environment media houses are under various pressures which compel them to write or speak which brings them more business. This raises many questions like; Does an editors' freedom end where the proprietor's eyebrow begins to rise? Is an editor custodian of the proprietor's interest? The fact can't be denied that the value of the newspaper will continue to be on the basis of its contents and this responsibility purely lies on the shoulder of the editor.

After deliberating on various market forces it can be said that we should not expect much from the market driven media. Star India Chief Executive Officer, Uday Shankar bluntly confesses that media from the day one was business oriented and further adds that it can't be run without the help of advertisers because after all money is required to meet different types of expenses. Certainly media may not be a tool for social reforms but it should not forget that if it is a business than it must have some corporate social responsibility and to fulfill that responsibility it must not forget the issues of social development which are of more concerned for the rural and people who are living below poverty line. If the story of rape case of one urban woman can be telecasted on 24 hours basis than the woman who lives in the rural areas and belongs to marginalized society also deserves the same treatment at least from the media houses but we feel sorry that it is not happening. 


\section{The Way Ahead}

Media conglomerates are largely run for business interests and not for the charity but one should not forget that a second stage revolution is possible through alternative media which generally originates from the people itself. However it is presumed that the term alternative media comes from the Western countries where it is described as the right to criticize the government actions and policies but it is always not true and can be a media for expressing the issues related to common man which are being generally ignored by the main stream media. Then there are many alternatives in the field of journalism may be in the form of blogs, smaller publications like Samyanter (Hindi magazine) owed by Mr. Pankaj Bist, Frontline can also be put in the category of alternative media which usually raise the issues of public concern and care for people, art films and many more.

If we talk about the film industry which is considered the most glamorous world and more oriented towards making profits and always keep running in the search of various markets which can help them to increase their TRP (Television Rating Points) ratings. But in this world also there are people who not only think but reflect their thinking in their films, such films are Peepli Live, which is a great example of showing the hijacking of real issues by the media houses, Paan Singh Tomer is also such film which has raised the real issues related to sports industry (more market oriented) and has even not a single incident of violence, whereas in the contemporary environment it is very difficult to find such films which raises the issues of such nature.

Community Radio is also such initiative taken by the Government of India where people are motivated to select their programs for community development along with the responsibility of acting as anchor and producer too, may be in the limited area or range where they live. In addition to all there are art films too which are the real representative of the people who are being ignored by the main media in the race of earning maximum market share. But it can't be denied that in the race of competition and to earn more and more market share the space for alternative media is shrinking and there is need to save the alternative media which is more people savvy.

\section{CONCLUSION}

Hence in the concluding part it can be said that the most disturbing development is that the wind of consumerism and globalization is so speedy that the media is spinning out of control from the grip of the editors and being controlled by various market forces. Even while following sports especially any cricket event one can find that the first and last ball of the over is being sacrificed to the advertisers because that match is being played with the power of money being paid by those advertisers and they are bound to oblige them. Not only the cricket or any other sports, even the news channels like Aaj Tak, which has the highest rating among the news channels, also shows news for one to one and half minute followed by six to seven minutes of advertisements and other channels, are also sailing in the same boat. Even in the race of this competition senior journalists are also not untouched and we know that recently Mr. Prasoon Vajpai shifted from Zee News to Aaj Tak and so is the case with the Prabhu Chawla who shifted from Aaj Tak to IBN 7 and there are n number of such cases which are being affected by the power of market and money. Now there is a need to find out some solution so that these media houses can be brought back on track and help in raising the issues related to common man. Nothing can be better than alternative media which is considered to be the real face of the people, but this is shrinking because of the increasing impact of the main media, and needs some upliftment. No doubt that such media is still alive and people are there to run such media and days are not far away when that media will again show its colors as it has been showing in the past.

\section{REFERENCES}

1. D.A. Seko (2007). Impact of Media and Advertising. Accessed on Jun 13, 2013.

2. Freedom of Speech. Anti Essays. Retrieved on January 18, 2013, from the World Wide Webhttp: / / w w w antiessays.com/freeessays/73776.html

3. Freedom of Speech by Hasbullzz279. Retrieved on Jun 18, 2012, from the World Wide Web http://www.freedomof speech.com

4. Karol Jakubowicz (2010). The Right to Public Expression: A Modest Proposal for an Important 
Human Right, Open Society Media Program.

5. Karol Jakubowicz (2004). Human Rights and the Information Society: A Preliminary Overview Council of Europe Preparatory Group on Human Rights, the Rule of Law and the Information Society 6. Monica Macovei (2004).Freedom of Expression (Human Rights Handbooks, No.2) Strasbourg Council of Europe. 2nd edition, January 2004.

7. McCombs, Maxwell E, and Donald L. Shaw (1977). The Emergence of American Political Issues. New York. West Publishing Co.

8. Namarta Joshi, Academic Disclosure, A Refereed Research Journal, Vol.1, No. 1, Jun 2012.

9 Onora O'Neill (2004). Rethinking Freedom of Press. Dublin: Royal Irish Academy.

10. Ranbir Singh (2012). Academic Disclosure, A Refereed Research Journal, Vol.1, No. 1, Jun 2012

11. Robert D. Leigh (1994). A Free and Responsible Press: A General Report on Mass Communication, edited by Commission on Freedom of the Press,

12. Http://www.un.org/en/documents/udhr/ index.shtml\#a19. Retrieved on Jun 16, 2013.

13. Http://www.indiantelevision.com/headlines/ y2k12/apr/apr129.php. Retrieved on May 02, 2013. 